\title{
DISPARIDADES INTRARREGIONALES EN EFICIENCIA Y PRODUCTIVIDAD DEL SISTEMA FINANCIERO Y DE SEGUROS DE MÉXICO
}

\section{INTRA-REGIONAL DISPARITIES IN EFFICIENCY AND PRODUCTIVITY OF FINANCIAL AND INSURANCE SYSTEM OF MEXICO}

Osvaldo U. Becerril Torres Universidad Autónoma del Estado de México obecerrilt@uaemex.mx
Gabriela Munguía Vázquez Universidad Autónoma del Estado de México gmunguia2000@hotmail.com
Joel Martínez Bello

Universidad Autónoma

del Estado de México Jmb9@hotmail.com

\section{RESUMEN}

Esta investigación tiene como objetivo determinar la eficiencia técnica, la productividad de los factores y sus componentes: cambios técnico y en eficiencia del sector de servicios financieros y de seguros de las regiones y entidades federativas de México. Las metodologías empleadas son DEA e índice de Malmquist. Los resultados muestran la existencia de disparidades inter e intra regionales en el sector. La productividad de éste se ha reducido, lo cual ha sido motivado de manera importante por la caída del cambio técnico, en tanto que no ha habido importantes cambios en la eficiencia y solamente en algunas entidades federativas ha mejorado.

Palabras clave: productividad total de los factores, cambio técnico, cambio en eficiencia, sistema financiero, disparidades intrarregionales.

Clasificación JEL: C14, G14, O16, O33, R12 


\begin{abstract}
This research aims to determine the technical efficiency and productivity of the factors and their components: technical change and efficiency change, of the sector of financial services and insurance of regions and states of Mexico. The methodologies used are DEA and Malmquist index. The results show us the existence of disparities, inter and intra-regional in the sector. The productivity is reduced, which has driven significantly by the fall of technical change, while there has been no major changes in efficiency and only in some states has improved.
\end{abstract}

Keywords: total factor productivity, technical change, efficiency change, financial system, intra regional disparities. 


\section{INTRODUCTION}

The current crisis which is observed in the major economies of the world has a strong link with the actions of the international financial system and the performance of local financial systems of the countries. Its performance has helped reveal the strengths and weaknesses of these. For its part, the international agencies ratings have been awarded the role of judges in the evaluation of the financial instruments of the countries and their financial institutions. On the other hand, an efficient financial sector allocates resources to business or investment projects with higher expected rates of return. In the case of Mexico, the financial and insurance sector is of particular relevance for economic activity because of their participation in the production. Information on the growth between year 2003 and 2008 reflects that was 67.8 per cent, ${ }^{1}$ while the investment recorded as gross fixed capital formation increased 257.9 percentage points, and the personnel employed in the sector, $74.2 \%$, while the number of economic units increased by $79.6 \%$. At the sector level, financial and insurance services contribute $6.2 \%$ of the total while investment brings $1.6 \%$ and the personal busy 1.7 percentage points.

Against this background and because of the importance acquired in recent years for the economic stability of countries, the question arises of how is the combination of the factors capital and labor in the financial and insurance system of Mexico being done and how has its productivity evolved $?^{2}$ The importance of answering these questions lies in identifying

\footnotetext{
1 Authors' calculations with data from INEGI Economic Census.

2 To answer this question has important implications on the quality of the investment and the technological gap arising from deficient systems of innovation, as well as the gap of productivity in the sector, as said in the document of the Latin American Integration Association, ALADI (2003) and Pollack and Garcia (2004).
} 
if the best practices are being carried out or is possible to make a better use of factors and, in this case, to make the best decisions.

A tentative answer to these questions is that there is no efficient use of factors and productivity in the sector has been reduced. To bring to fruition this analysis is necessary to generate indicators that allow us to test these hypotheses.

For this, to count with indicators that reveal the performance of financial systems and in particular for Mexico and its regions ${ }^{3}$, in the context of financial and insurance system, provides elements for better decision making in this area, as it enables a quantification on the practices that are carried out regarding the use of factors of production. In the international context, there are a variety of studies that allow a better understanding of what happens to the local financial systems and their relationship, for example, with the economic growth. Thus, Pollack and Garcia (2004) argue that there is a clear relationship between the growth and development of the financial system, since this reduces the cost of capital, promoting with its economic growth and, in a global context, increases the competitiveness of the economy. For this reason -as said by Pollack and Garcia- all global competitiveness reports include the financial sector as one of the factors that determine the efficiency of the business. An example of this can be seen in the 2012-2013 Global Competitiveness Report 2012-2013 edited by Klaus (2012), where 12 pillars of competitiveness, are defined and one of them is related to the development of the financial market; this due to the fact that an efficient financial sector allocates to its most productive uses the resources saved by the citizens of the nation, as well as entering the economy from abroad. Thus also channeled resources to business projects or investment with higher rates of return expected.

3 The analysis by regions is of interest since by the way they are methodologically grouped, it should provide correlational evidence of performance in efficiency and productivity. 
Analysis techniques are varied, from actuarial models to sophisticated econometric models. In particular, in the economic analysis of production there are two techniques that are widely used to measure how an organization makes use of its factors of production; these are the Data Envelopment Analysis and Stochastic Frontier Analysis. They allow identifying the existence of inefficiencies in the use of factors.

Since the pioneer labour of Solow (1956), the growth of productivity or technical progress has been associated with the derivation of the production function. However, this is no longer so suitable for the measurement of productivity using index numbers, since the procedure of index numbers involves comparison using discrete data, and therefore requires a discrete approximation to the derivative at the time. ${ }^{4}$ This is why Caves, Christensen and Diewert (1982) proposed a context for input, output, and measures of productivity, not coming from a representation in continuous time. For this they use a general framework for the structure of production using prices and quantities of inputs and outputs, based on the notion of Malmquist index at input and output, known as the index of productivity. Thus, the antecedent is located in Moorteen (1961), who proposed the idea of the Malmquist (1953) index in the context of the consumer, suggesting to compare the input of each company in two different moments in time, in terms of the maximum factor by which the input over a period can be reduced such that the firm still produces the output levels observed in another period of time.

By the foregoing, Caves, et al. (1982) developed the idea of a reduction or Malmquist deflation in the context of unrestricted production structures for two time periods. They propose a set of theorems establis-

4 However, the contribution of Solow is recognized for his contributions to the understanding of productivity, and that later serves as basis to Mankiw, Romer and Weil (1992) to incorporate in the analysis to human capital. 
hing them for foregoing production structures, that are suggested as an average of two Malmquist indexes which can be computed using prices and quantity data only, with decreasing and constant returns to scale and, in the case of increasing returns to scale, their computation would require knowing the degree of returns to scale. Thus, allow each company to have its own foregoing ${ }^{5}$ frontier.

Thus in recent years has been accepted that there may be inefficiencies in the use of productive factors when combined, to get the maximum possible production, technical efficiency, the technological frontier and the productivity of the factors affecting, and before this, opens a set of lines of work aimed at establishing techniques and methods for measurement and application to different fields of study.

Empirical evidence which makes use of this Frontier type of calculations, allows in the use of private productive factors such as the empirical works of Gumbau and Maudos (1996), Beeson and Husted (1989), and others. Among the works that are based on techniques not parametrical are identified by Maudos, Pastor and Serrano $(1998,1999)$ and Salinas, Pedraja and Salinas (2001). Recently Griffin and Woodward (2011) apply these techniques to the fisheries sector. Meanwhile Brown and Domínguez (2004), Fuentes and Armenta (2006), Navarro and Torres (2006), Alvarez et al (2008), Celso and Cortes (2010) and Ablanedo and Gemoets (2010) used these techniques in the case of Mexico.

Thus, the use of these non-parametric techniques contributes, as an alternative and complementary way to perform measurements in the financial context. In the international context, there are some works such as Mariaca (2003), Marin, Gomez and Candide (2008), Belmonte and Plaza

5 Revise Christensen, Jorgenson and Lau (1973) for a detailed analysis on this type of production functions. 
(2008) and Guzmán and Escobar (2011), and others, all of them are examples of its use in this area. In Mexico there are few investigations that contribute to the understanding of the functioning of the sector, some of the works that can be identified are Guerrero and Negrín (2006) and Hernandez (2007). However, there are no works in this country that identify the form which makes use of factors (technical efficiency) in the financial system and insurance or the way in which evolves its productivity. That is why the objective of this research is therefore to contribute to the understanding of the way in which it makes use of factors and how has the productivity evolved of the financial and insurance sector of Mexico, from a perspective with orientation in the economic science.

For this purpose, data envelopment analysis and Malmquist index techniques are used for the generation of indicators. The second section of this paper, we present in detail the data envelopment analysis and the Malmquist index; in the third section characteristics of the data and the sources used are reported, in the fourth section the main results obtained from regions and the federal entities are presented. Finally, in section five, the main conclusions and proposals are reported.

\section{METHODOLOGY}

The calculation of inefficiency has led the main motivation in the study of the production frontiers. There are two approaches in the construction of frontiers: one of them is based on mathematical programming techniques, while the other uses econometric tools. The main advantage of mathematical programming or "Data Envelopment Analysis" (DEA) approach is that it does not need to impose an explicit functional form on the data. 
Although the obtained frontier may be distorted if it is contaminated by statistical noise. For its part, the econometric approach takes into account the statistical noise, but imposes a functional form perhaps restrictive technology. This research focuses on non-parametric approach.

From the viewpoint of non-parametric, empirically implemented efficiency measures developed by Farrell (1957) using linear programming methods, called Data Envelopment Analysis (DEA). Farrell suggested that efficiency of a unit decision $\left(\mathrm{DMU}^{6}\right)$ is comprised of two components: "technical efficiency", which reflects the ability to obtain the maximum output for a given set of inputs, and the "efficiency in price or allocate", which reflects the ability to use the inputs in the best proportions, given their respective prices. This analysis focuses on the efficiency measures output-oriented, responding to the question on how the output can be expanded without altering the amount of necesaary inputs ${ }^{7}$.

The DEA model of calculating of technical efficiency and scale that occurs is developed in Seiford and Thrall $(1990)^{8}$. Its purpose lies in building a non parametric production possibility frontier, which wraps the data. Thus, when considering $\mathbf{N}$ units of decision where each DMU consumed quantities $\mathbf{M}$ inputs to produce $\mathbf{S}$ outputs. Specifically, the $\mathrm{DMU}_{\mathrm{j}}$ consumes $\mathbf{X}_{\mathrm{ji}}$ input $i$ and produces $\mathbf{Y}_{\mathrm{jr}}$ output $\mathrm{r}$. It is assumed that $\mathrm{X}_{\mathrm{ji}} \geq 0$. Also, $\mathbf{X}$ and $\mathbf{Y}$ are matrices of size $\mathbf{M x N}$ and $\mathbf{S x N}$, they containing all inputs and outputs corresponding to the N DMU's considered (in this study, the $\mathrm{j}$-th DMU makes reference to the $\mathrm{j}$-th region, with $\mathrm{j}=1,2, \ldots, 7$ ).

\footnotetext{
6 DMU, "Decision Making Unit", which is a broader term than firm

7 Equivalently, efficiency measures input-oriented maintain constant output level, allowing to estimate the extent it is possible to reduce the amount of inputs.

8 Standard models which carry out the calculation of technical and scale efficiencies develop in Fare, Grosskopf and Lovell (1994).
} 
For a DMU for its input/output ratio provides a measure of efficiency. In mathematical programming this ratio, which is minimized, constitutes the objective function of the analyzed DMU. For its part, the standard restrictions reflected the condition that each DMU input/output ratio must be greater than the drive, so calculated input-output frontier wrap corresponding to all considered DMU's different combinations. The mathematics program for the efficiency ratio will therefore be:

$$
\begin{aligned}
& \operatorname{Min} v^{T} x_{0} / u^{T} y_{0} \\
& u, v \\
& \text { s.t. } v^{T} x_{j} / u^{T} y_{j} \geq 1 \quad j=1,2, \ldots, N \\
& u \geq 0 \\
& v \geq 0
\end{aligned}
$$

Where the variables are $u$ and v, vectors of size Sx1 and Mx1, respectively. In this way, the optimal weights are calculated $\mathrm{u} *$ and $\mathrm{v} *$, associated with the outputs and inputs.

However, this latter problem provides endless solutions, for which the restriction is incorporated $\mu^{\mathrm{T}} \mathrm{y}_{0}=1$, leads to obtain $\mathrm{m}$ and $\mathrm{n}$ as a result of the transformation:

$$
\begin{aligned}
& \operatorname{Min} v^{T} x_{0} \\
& \mu, v \\
& \text { s.t. } \mu^{\mathrm{T}} \mathrm{y}_{0}=1 \\
& v^{\mathrm{T}} \mathrm{X}-\mu^{\mathrm{T}} \mathrm{Y} \geq 0 \\
& \mu^{\mathrm{T}} \geq 0 \\
& v^{\mathrm{T}} \geq 0
\end{aligned}
$$


Whose dual problems are:

$\operatorname{Max} \phi$

$\phi, \lambda$

$$
\begin{aligned}
& \text { s.t. } X \lambda \leq x_{0} \\
& \phi y_{0}-Y \lambda \leq 0 \\
& \lambda \geq 0
\end{aligned}
$$

Where $\varphi$ is a scalar for optimize and $\lambda$ is a vector $\mathrm{Nx} 1$.

The process is repeated for each $\mathrm{DMU}_{\mathrm{j}}$, introduced in the previous problem $\left(\mathrm{x}_{0}, \mathrm{y}_{0}\right)=\left(\mathrm{x}_{\mathrm{j}}, \mathrm{y}_{\mathrm{j}}\right)$. One DMU is inefficient if $\phi^{*}<1$ and efficient if $\phi^{*}=1$. Therefore, all efficient DMU are placed on the production possibility frontier. However, a DMU is placed at the frontier $\left(\phi^{*}=1\right)$ and be inefficient. Restrictions lead to efficiency in the point $\left(\mathrm{x}_{0}, \mathrm{y}_{0}\right)$ for one $\lambda^{*}$ optimal when these are met with equal, we have to say $x_{0}=X \lambda^{*} y$ $\mathrm{y}_{0}=\mathrm{Y} \lambda^{*}$. An inefficient DMU can become more efficient when projected on the frontier. Although it's necessary to distinguish between a frontier and an efficient frontier point. For an output orientation of the projection $\left(\mathrm{x}_{0}, \mathrm{y}_{0}\right) \rightarrow \Delta\left(\mathrm{x}_{0}, \phi^{*} \mathrm{y}_{0}\right)$ always leads to a frontier point, but the technical efficiency is only reached if $\mathrm{x}_{0}=\mathrm{X} \lambda * \mathrm{y} \phi^{*} \mathrm{y}_{0}=\mathrm{Y} \lambda^{*}$, for all $\lambda^{*}$ optimum. Then, to achieve technical efficiency total restrictions must be met with equal.

The raised model assumes constant returns to scale, in which case the measures of efficiency input-oriented and output-oriented are equivalent Fare and Lovell (1978). However, the imperfections in the market, restrictions financial, among others, may cause a DMU to stop operating at optimal levels. For this reason, Banker, Charnes, and Cooper (1984) extend the model assuming variable returns to scale, allowing you to calculate scale efficiencies. To do so, the restriction must be

$\mathrm{e}^{\mathrm{T}} \lambda=1$ (" $\mathrm{e}$ " is a vector whose components are unity and size $(\mathrm{Nx} 1)$ in the model (2.1), retrieved from: 
$\operatorname{Max} \phi$

$\phi, \lambda$

$$
\begin{array}{ll}
\text { s.t. } & \mathrm{X} \lambda \leq \mathrm{x}_{0} \\
& \mathrm{y}_{0}-\mathrm{Y} \lambda \leq 0 \\
\lambda \geq 0 & \\
\mathrm{e}^{\mathrm{T}} \lambda=1
\end{array}
$$

Analytically, the restriction $\mathrm{e}^{\mathrm{T}} \lambda=1$ generates a requirement of convexity which obliges the efficient frontier of possibilities of production to consist of segments that unite the extreme points. In this way, has achieved a measure of pure technical efficiency (without scale efficiencies). However, the efficiency of scale measurements obtained using this procedure does not indicate when the DMU operates in an area of increasing or decreasing yields. For this reason, an alternative model, incorporating the restriction $\mathrm{e}^{\mathrm{T}} \lambda=1$ (not allow increasing yields) arises in this model (2.1.):

\section{$\operatorname{Max} \phi$}

$\phi, \lambda$

$$
\begin{gathered}
\text { s.t. } \mathrm{X} \lambda \leq \mathrm{x}_{0} \\
\phi \mathrm{y}_{0}-\mathrm{Y} \lambda \leq 0 \\
\lambda \geq 0 \\
\mathrm{e}^{\mathrm{T}} \lambda \leq 1
\end{gathered}
$$

The nature of the efficiencies of scale for a particular DMU is determined by comparing the obtained technical efficiency measures through the implementation of models (2.2), which are yielding variables to scale, and (2.3), which only allow diminishing returns to scale. Thus, if they match in both models, then considered DMU has diminishing returns to scale (in otherwise, increasing returns). 


\subsection{Measurement of the growth of TFP and its components.}

To carry out this analysis has a panel of data, so it is possible to calculate the Malmquist index, following the methodology proposed by Fare, et al. (1994). This index allows you to break down the growth of productivity in two components: changes in the technical efficiency and technology over time. As mentioned, the technical efficiency measurement can be oriented to the input (when, given a level of output, is to minimize the quantities to consume different inputs) or output (when, given a level of inputs, is necessary to expand the output as much as possible). For the subsequent empirical application, attention will focus on the technical efficiency calculation based on an output orientation.

In this document the change in productivity as the geometric mean of two Malmquist productivity index is calculated. To define the Malmquist index based on the output, it will be assumed that in each period $t=1, \ldots \mathrm{T}$, the technology for production.

$S^{t}$ modeling the transformation of the inputs, $x^{t} \in \mathscr{R}_{+}^{N}$ into outputs, $Y^{t} \in \mathscr{R}_{+}^{N}$

$\mathrm{S}^{\mathrm{t}}=\left\{\left(\mathrm{X}^{\mathrm{t}}, \mathrm{Y}^{\mathrm{t}}\right): \mathrm{X}^{\mathrm{t}}\right.$ can produce $\left.\mathrm{Y}^{\mathrm{t}}\right\}$

For its part, the output $t$ distance function is defined as:

$$
D_{0}^{t}\left(X^{t}, Y^{t}\right)=\inf \left\{\phi:\left(X^{t}, Y^{t} / \phi\right) \epsilon S^{t}\right\}=\left(\sup \left\{\phi:\left(X^{t}, \phi Y^{t}\right) \epsilon S^{t}\right\}\right)^{-1}
$$

This function is defined as the reciprocal of the highest proportional expansion of output vector $\mathrm{Y}^{\mathrm{t}}$, given the inputs $\mathrm{X}^{\mathrm{t}}$, and have many characteristics than complement the technology. In particular, $D_{0}^{t}\left(X^{t}, Y^{t}\right) \leq 1$ iff $\left(X^{t}, Y^{t}\right) \in S^{t}$. In addition, $D_{0}^{t}\left(X^{t}, Y^{t}\right)=1$ if $\left(X^{t}, Y^{t}\right)$ It is on the technological 
frontier. In the terminology of Farrell (1957) that occurs when production is technically efficient.

The distance function definition follows that it is homogeneous of degree one in outputs. Additionally, it is the reciprocal of the measurement of technical efficiency in the output of Farrell (1957).

To develop the Malmquist index, it is necessary to define the functions of distance from two different periods as:

$$
D_{0}^{t}\left(X^{t+1}, Y^{t+1}\right)=\inf \left\{\phi:\left(X^{t+1}, Y^{t+1} / \phi\right) \epsilon S^{t}\right\}
$$

The distance function corresponding to (2.6.) measures the maximum proportional change in outputs required to achieve that $\left(\mathrm{X}^{\mathrm{t}+1}, \mathrm{Y}^{\mathrm{t}+1}\right)$ feasible in relation to technology in t. Similarly, you can define a distance function that measures the maximum ratio of change in output necessary for the combination $\left(\mathrm{X}^{\mathrm{t}}, \mathrm{Y}^{\mathrm{t}}\right)$ feasible in relation to technology in $\mathrm{t}+1$, that we called. Thus, the output of the Malmquist productivity index is defined as:

$$
M^{\mathrm{t}}=\frac{D_{0}^{\mathrm{t}}\left(X^{\mathrm{t}+1}, Y^{\mathrm{t}+1}\right)}{D_{0}^{\mathrm{t}}\left(X^{\mathrm{t}}, Y^{\mathrm{t}}\right)}
$$

Where $t$ technology, is the technology of reference. Alternatively, defines a Malmquist index based on the period $t+1$ :

$$
M^{t+1}=\frac{D_{0}^{t+1}\left(X^{t+1}, Y^{t+1}\right)}{D_{0}^{t+1}\left(X^{t}, Y^{t}\right)}
$$

The choice of one or another reference technology is important. For this reason, solving the problem that can represent the consideration of a fixed technology, Fare, et al. (1994) define the index of Malmquist productivity change based on the output and the average of Geometrics of the 
Malmquist indexes (2.7) (2.8), pre-specified:

$$
M_{0}\left(X^{t+1}, Y^{t+1}, X^{t}, Y^{t}\right)=\left[\left(\frac{D_{0}^{t}\left(X^{t+1}, Y^{t+1}\right)}{D_{0}^{t}\left(X^{t}, Y^{t}\right)}\right)\left(\frac{D_{0}^{t+1}\left(X^{t+1}, Y^{t+1}\right)}{D_{0}^{t+1}\left(X^{t}, Y^{t}\right)}\right)\right]^{1 / 2}
$$

Or equivalently:

$$
M_{0}\left(X^{t+1}, Y^{t+1}, X^{1}, Y^{t}\right)=\frac{D_{0}^{t+1}\left(X^{t+1}, Y^{t+1}\right)}{D_{0}^{t}\left(X^{t}, Y^{t}\right)} x\left[\left(\frac{D_{0}^{t}\left(X^{t+1}, Y^{t+1}\right)}{D_{0}^{t+1}\left(X^{t+1}, Y^{t+1}\right)}\right)\left(\frac{D_{0}^{t}\left(X^{t}, Y^{t}\right)}{D_{0}^{t+1}\left(X^{t}, Y^{t}\right)}\right)\right]^{1 / 2}
$$

Expression (2.10) allows you to divide the evolution that continues the productivity in two components. The first component refers to the change in efficiency, whose improvements are considered to be evidence of "catching-up", i.e., of each of the DMU's approaches to the efficient frontier. ${ }^{9}$ For its part, the second component indicates how vary the technical change, i.e. how the displacement of the efficient frontier to the input of each DMU is generating an innovation in the latter. Improvements in the Malmquist index of change in productivity lead to values above the unit, as is the case with every one of its components. In addition, note that this decomposition provides an alternate way contrast convergence in the growth of productivity, as well as to identify the innovation. In the empirical work is calculated the Malmquist productivity index using parametric programming techniques exposed previously. ${ }^{10}$ Thus, to calculate productivity of the $\mathrm{k}$-th the DMU between $\mathrm{t}$ and $\mathrm{t}+1$, must solve four linear programming problems: $D_{0}^{t}\left(X^{t}, Y^{t}\right), D_{0}^{t+1}\left(X^{t}, Y^{t}\right), D_{0}^{t}\left(X^{t+1}, Y^{t+1}\right)$ y $D_{0}^{t+1}\left(X^{t+1}, Y^{t+1}\right)$. To do so, makes use of the fact that the output distance function is reciprocal to the extent of technical efficiency of the output-oriented Farrell.

9 Programming methods using non-parametric efficient frontier is constructed for the regions of Mexico.

10 The output-oriented DEA model posed in Seiford and Thrall (1990) is substantially modified by considering the variation in time. 
Suppose $\mathrm{k}^{\prime}=1,2, \ldots, \mathrm{K}$ DMU's using $\mathrm{n}=1,2, \ldots, \mathrm{N}$ inputs in each period $\mathrm{t}=1,2, \ldots, \mathrm{T}$. These inputs are used to produce $\mathrm{m}=1, \ldots, \mathrm{M}$ outputs . Therefore, for each $\mathrm{k}=1, \ldots, \mathrm{K}$ calculated:

$$
\begin{aligned}
& \left(D_{0}^{t}\left(X^{k^{\prime}, t+1}, Y^{k^{\prime}, t+1}\right)\right)^{-1}=\max \phi^{k^{\prime}} \\
& \text { s.t. } \quad \phi^{k^{\prime} y^{k^{\prime} t}} \leq \sum_{k=1}^{k} \lambda^{k, t} y_{m}^{k, t} \\
& \sum_{k=1}^{k} \lambda^{k, t} x^{k, t} \leq x_{n}^{k^{\prime}, t} \\
& \lambda^{k, t} \geq 0
\end{aligned}
$$

The measure of $D_{0}^{t+1}\left(X^{k^{\prime}, t+1}, Y^{k^{\prime}, t+1}\right)$ is performed as in (2.11), substituting $\mathrm{t}$ +1 in $\mathrm{t}$. Two of the distance functions used in the construction of the Malmquist index requires information about the two periods. The first one is computed for observation $\mathrm{k}$ as:

$$
\begin{aligned}
& \left(D_{0}^{t}\left(X^{k^{\prime}, t+1}, Y^{k^{\prime}, t+1}\right)\right)^{-1}=\max \phi^{k^{\prime}} \\
& \text { s.t. } \quad \phi^{k^{\prime}} y_{m}^{k^{\prime}, t+1} \leq \sum_{k=1}^{k} \lambda^{k, t} y_{m}^{k, t} \\
& \sum_{k=1}^{k} \lambda^{k, t} x^{k, t} \leq x_{n}^{k^{\prime}, t+1}
\end{aligned}
$$

In (2.12) Appear observations of $t$ and $t+1$, at the same time, since technology with respect to which $\left(X^{k, t+1}, Y^{k, t+1}\right)$ is evaluated in correspondent to $t$. In (2.11.), $\left(X^{k^{\prime}, t}, Y^{k^{\prime}, t}\right) \in S^{t}$, and therefore $D_{0}^{t}\left(X^{k^{\prime}, t}, Y^{k^{\prime}, t}\right) \leq 1$. However, in (2.12), $\left(X^{k^{\prime}, t+1}, Y^{k^{\prime}, t+1}\right)$ does not have to correspond to $S^{t}$, bringing $D_{n}^{t}\left(X^{k^{\prime}, t+1}, Y^{k^{\prime}, t+1}\right)$ It can take values higher than the unit. The last linear programming problem you need to solve is also a joint problem, as (2.12) but transposing $t$ and $t+1$. 
To analyze changes in the efficiencies of scale, is also calculated the distance functions under returns to scale variables ${ }^{11}$, incorporating the following constraint to the previous models: $\sum_{k=1}^{k} \lambda^{k t}=1$.

Efficiency at scale in each period is constructed as the quotient between the distance with constant yields function and variable yield which meets. On the other hand, technical change is calculated in relation to the technology with constant yields.

\section{DATABASES AND SOURCES OF INFORMATION USED}

The data on financial services and insurance ${ }^{12}$ of the federal entities considered come from the economic censuses of Mexico, corresponding from 2003 to 2008. The product is represented by the Total Gross Production, ${ }^{13}$ TGP, which is the value of goods and services produced by the economic unit, as a result of the exercise of their activities; Investment is incorporated through the gross formation of fixed Capital, ${ }^{14}$ GFFC, which is the value of the fixed assets purchased by the economic unit, discounting the value of fixed assets sold and employment is referred to by the indicator busy staff total, ${ }^{15} \mathrm{ST}$, in the private and non-state sector economic units. The statistical source from which these databases have been obtained is the Economic Census of the National Institute of Statistics and Geography of Mexico, INEGI (2004, 2009).

11 See Banker, Charnes and Cooper (1984).

12 Annex A-1 shows the sector, subsector, branch and sub-branch of this economic activity.

13 This is a general concept that aims to be inclusive of all types of local economic activity. It is expressed in monetary units, usually in thousands of pesos.

14 It is expressed in monetary units.

15 Includes staff employed directly, with others, provided by another firm, which works for the economic unit, subject to the direction and control, covering at least one third of their working time in the same. 
Socioeconomic regions are obtained from the classification of the INEGI, who prepares the legal order based on the information of the XII General Census of Population and Housing, 2000 (INEGI, 2000), using the method proposed by Jarque (1981) to form groups or strata, which was originally established as a solution to the problem of optimum stratification in multi-parametric sampling. Therefore form seven (different from one another) strata, where elements classified in the same group have on average similar characteristics that make them are homogeneous. The layers are sorted in such shapes which are the Federal States that have the most favorable situation related to the variables; on the other hand, on average in the 7 layer stratum 1 consists of units which on average are less favourable situation. ${ }^{16}$

The method aims to form strata with minimum variance looking to items that most look like each other or that are closest, following an established criterion of similarity and which in turn allows to differentiate one layer of another group. Derived from the application of this methodology in table 1 are shown the socioeconomic regions of Mexico, which can be viewed on the map 1 .

Table 1

Socioeconomic regions of Mexico

\begin{tabular}{|l|l|l|l|l|l|l|}
\hline Region 1 & Region 2 & Region 3 & Region 4 & Region 5 & Region 6 & Region 7 \\
\hline Chiapas & Campeche & Durango & Colima & Baja California & Aguascalientes & $\begin{array}{l}\text { Distrito } \\
\text { Federal }\end{array}$ \\
\hline Guerrero & Hidalgo & Guanajuato & México & Baja California Sur & Coahuila & \\
\hline Oaxaca & Puebla & Michoacán & Morelos & Chihuahua & Jalisco & \\
\hline & $\begin{array}{l}\text { San Luís } \\
\text { Potosí }\end{array}$ & Tlaxcala & Nayarit & Sonora & Nuevo León & \\
\hline & Tabasco & Zacatecas & Querétaro & Tamaulipas & & \\
\hline
\end{tabular}

16 Education, employment, housing, construction, and socioeconomic status, the latter comprises 24 indicators selected topic. 


\begin{tabular}{|l|l|l|l|l|l|l|}
\hline & Veracruz & & Quintana Roo & & & \\
\hline & & Sinaloa & & & \\
\hline & & & Yucatán & & & \\
\hline
\end{tabular}

Sourse: http://sc.inegi.org.mx/niveles/index.jsp, accessed April 14, 2011

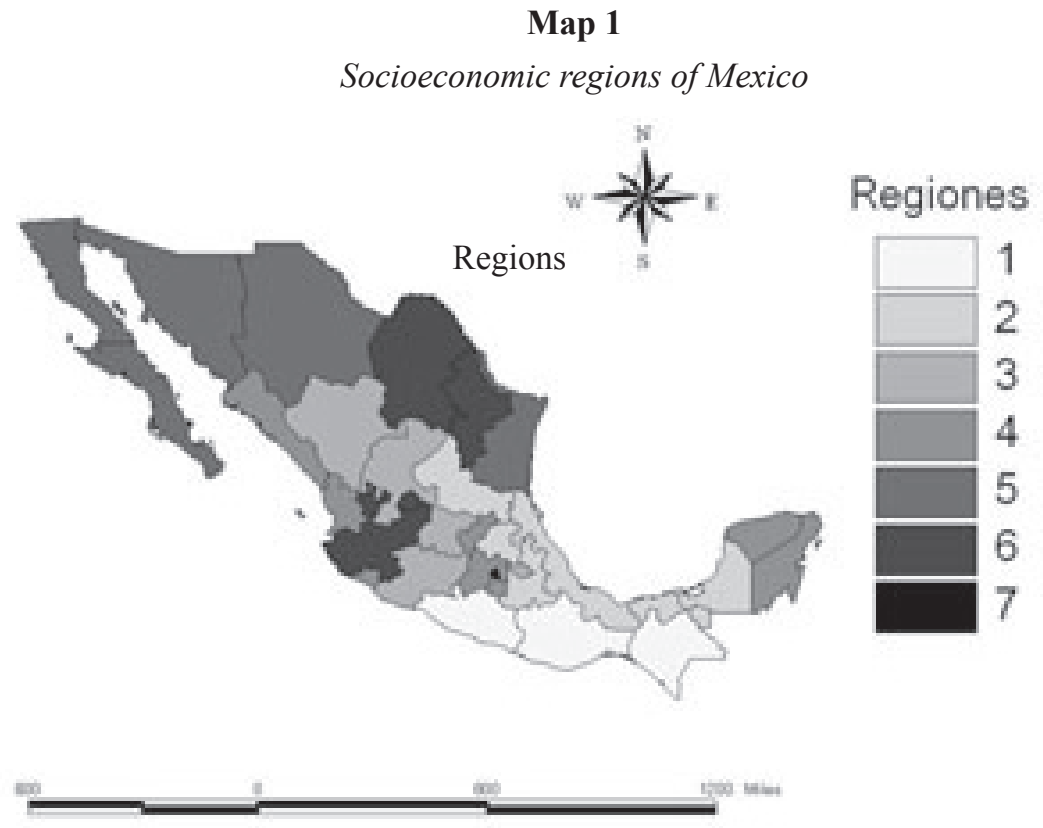

Source: Based on data from INEGI.

The sectorial classification that used is based in the INEGI (2004, 2009), which is organized according to the system of the North America industry classification, NAICS, Mexico, 2007 by INEGI (2008) and data from sector 2, financial services and insurance, are available in those censuses.

From this classification and the application of equations 2.1, 2.2 and 2.3 is obtained the technical efficiency of financial services and insurance that then occurs. 


\section{RESULTS}

From the obtaining of the ratios of relative inputs to output, which are presented in the Annex A-2, found the technological frontier and regions about this position. In figures $1 \mathrm{a}$ and $1 \mathrm{~b}$, shown frontiers for the years 2003 and 2008 financial services and insurance of the regions, noting that in the Federal District is what determines such a frontier. However, for the year 2008, is bounded by the Federal District and the States of the region 6 (Aguascalientes, Coahuila, Jalisco and Nuevo León), what would be reflecting a process of financial decentralization or further development in these States. Note that the end of the period, in the year 2008 is observed a greater dispersion in the positioning of the regions with respect to the efficient frontier.

\section{Figure 1a}

Technological frontier regions of Mexico, 2003

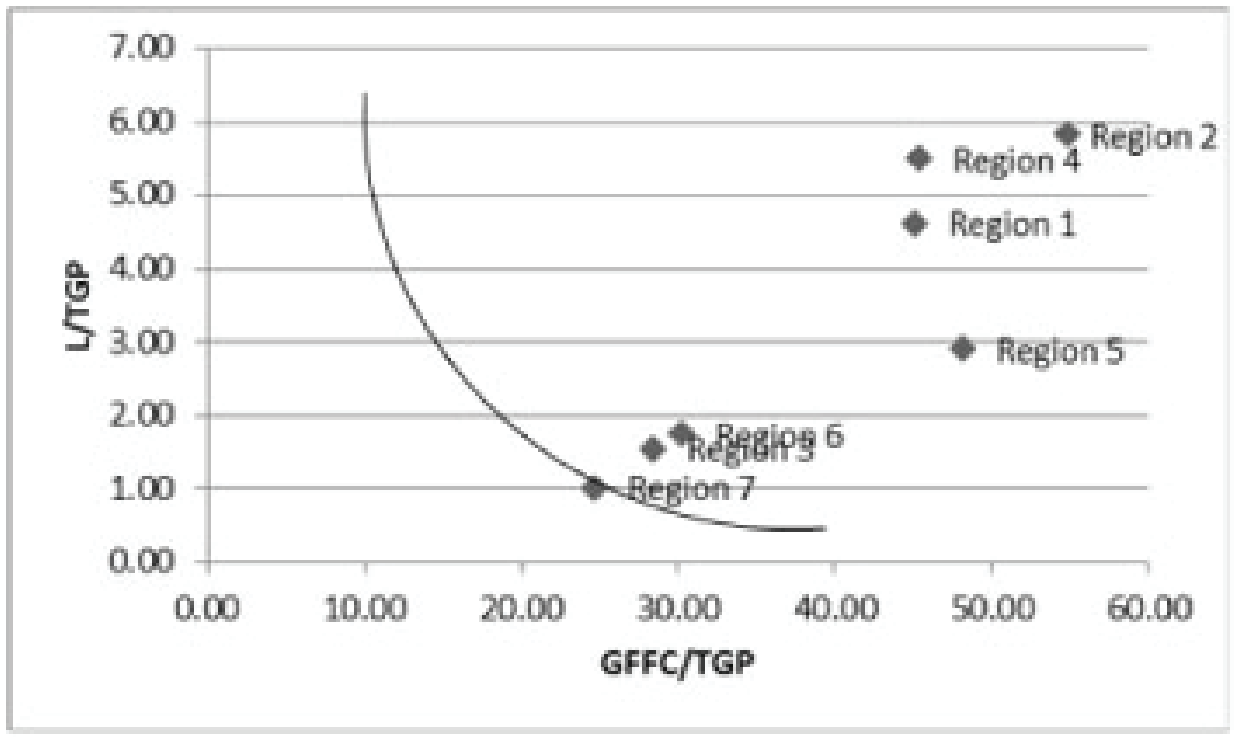

Source: Based on data from INEGI. 
Figure 1b

Technological frontier regions of Mexico, 2008

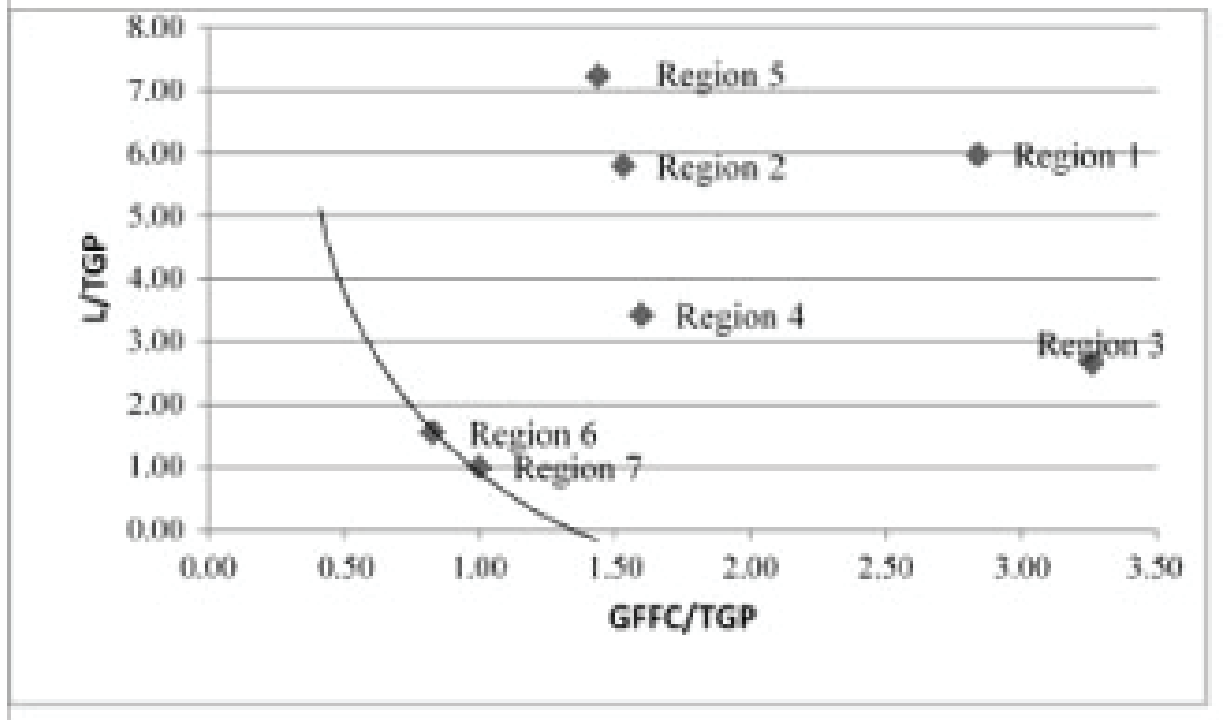

Source: Based on data from INEGI.

A frontier of optimum production with productive factors available (capital and employment) of the financial and insurance sector the regions of Mexico are determined from equations 2.1 to 2.3. The calculation of technical efficiency is through the use of the software DEAP $2.1,{ }^{17}$ which is based on the method of estimation of multiple stages for the resolution of DEA models described in Coelli (1998). With the implementation of the equations (2.1) and (2.2) technical efficiency is determined. Therefore if a region is efficient in the sense of scale constants yields, $\mathrm{CRS}^{18}$, then will be efficient scale both technically, so its efficiency of scale will be equal to

17 Coelli (1996).

18 Constant Returns to Scale. When a DMU, in this case, a region, its output increases with increased less than proportionally resources, is said to possess increasing returns. When the opposite occurs yields are decreasing. If the volume of activity increases in the same proportion as inputs or outputs, it is said that the returns are constant to scale. 
one. From this, table 2 show efficient regions in the CRS sense which are the 5, 6 and 7 both in 2003 and 2008 .

However, competitive markets do not always exist inside economies, so the existence of imperfections in the market, restrictions on access to capital, or non-optimal levels of qualification of the workers, among other distorting factors, cause they let their production systems operate on scale optimal, by allowing the technical efficiency with variable returns to scale to identify, in this study, regions that perform the best practices under this scheme and is determined that from them the efficiency of other, so also in the table 2 identifies four regions were more efficient in 2003 under VRS (regions 1, 5, 6 and 7), which are identified by having a unit value in the technical efficiency indicator. In 2008, we exclude the region 1.

Table 2

Technical Efficiency and constant returns to scale variables

\begin{tabular}{|c|c|c|c|c|}
\hline Region & $\begin{array}{c}\text { Technical efficiency with } \\
\text { constant returns to scale } \\
\text { (2003) }\end{array}$ & $\begin{array}{c}\text { Technical efficiency with } \\
\text { constant returns to scale } \\
(2008)\end{array}$ & $\begin{array}{c}\text { Technical efficiency with } \\
\text { variable returns to scale } \\
(2003)\end{array}$ & $\begin{array}{c}\text { Technical efficiency with } \\
\text { variable returns to scale } \\
(2008)\end{array}$ \\
\hline 1 & 0.36 & 0.20 & 1.00 & 0.20 \\
\hline 2 & 0.57 & 0.40 & 0.84 & 0.40 \\
\hline 3 & 0.57 & 0.59 & 0.57 & 0.59 \\
\hline 4 & 0.78 & 0.78 & 0.78 & 0.78 \\
\hline 5 & 1.00 & 1.00 & 1.00 & 1.00 \\
\hline 6 & 1.00 & 1.00 & 1.00 & 1.00 \\
\hline 7 & 1.00 & 1.00 & 1.00 & 1.00 \\
\hline Average & 0.75 & 0.71 & 0.88 & 0.71 \\
\hline
\end{tabular}

Source: Based on data from INEGI.

In average terms, technical efficiency was 0.88 under CRS for the year 2008 and 0.71 under VRS for the same year, which indicates that even you can expand production in most regions by making better use of production factors, given that this analysis of oriented output type. Likewise, 
continuing with the application of the methodology exposed previously, and from the equation 2.6, which is used to calculate distances, calculate the Malmquist index raised in the equation (2.9) and whose results are presented below.

As shown in table 3, the behavior of the change in productivity has been influenced significantly by technological change since this is that it has most contributed to his fall, so as to be less than the unit, it reflects deterioration in this. Respect to technical change, it has suffered a setback in all regions, while in the case of efficiency change most regions show unit values (regions 3, 4, 5, 6 and 7), indicating that the use of factors has been unchanged, however the regions 1 and 2 have worsened, while three is the only one that offers improvements in the use of the factors (of three percentage points) causing a shift towards its frontier optimal (derived from the equation 2.5).

Thus, this analysis allows identifying regions that were the best practices in the use of production factors as suggested Kruger, Cantner and Hanush (2000) and Lanteri (2002). (Regions that produce efficiently are located in the technological frontier). The majority of the regions show no change in technical efficiency so your relative productivity remains unaltered.

Table 3

Decomposition of Total Factor Productivity regional

\begin{tabular}{|c|c|c|c|}
\hline Region & TFP Change & Technical change & Efficiency change \\
\hline 1 & 0.53 & 0.96 & 0.55 \\
\hline 2 & 0.48 & 0.69 & 0.70 \\
\hline 3 & 0.53 & 0.51 & 1.03 \\
\hline 4 & 0.51 & 0.51 & 1.00 \\
\hline 5 & 0.73 & 0.73 & 1.00 \\
\hline 6 & 0.52 & 0.52 & 1.00 \\
\hline 7 & 0.52 & 0.52 & 1.00 \\
\hline Average & 0.54 & 0.62 & 0.88 \\
\hline
\end{tabular}

Note: All Malmquist indices are the average of the geometric means of each region.

Source: Based on data from INEGI. 
In general, the change in productivity over the period due to changes in optimal productivity of production or technical change (caused by the less developed technology incorporation processes, impeding the movement favorably the production frontier. On the other hand, the change in efficiency is maintained in at unit value, what keeps unchanged the production boundary.

With the interest to deepen the analysis of the pattern of productivity growth, figure 2 shows the rate of productivity of Malmquist from each of the regions, as well as its components: technical change and change in efficiency. As can be seen, it provides evidence that technical change is highly correlated with TFP (derived from the equation 2.10), while the change in efficiency presents a less intense degree of Association since to be closer to the unit, the implication is that it does not contribute importantly to change in TFP. Thus, it can be inferred that the incorporation of technological improvements and through the specialization of the workforce mainly, you will have a strong impact on the productivity of the sector in the regions of the country.

Figure 2

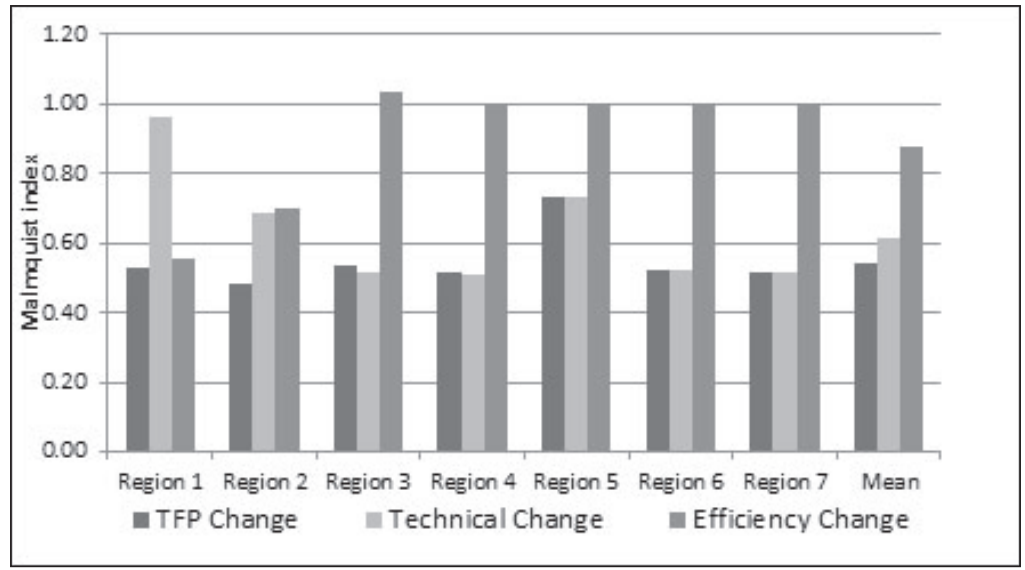

Source: Based on data from INEGI. 
The intra-regional study shows the particularities of States in terms of the change in productivity in its components: technical change and efficiency change. Thus, to have a better understanding of the behavior of these, the following analysis is performed to identify intra-regional disparities. As mentioned previously for the region 1, TFP in the financial sector showed a decline, driven higher by the change in efficiency. To the interior of the region, the change in efficiency of States that integrate (Chiapas, Guerrero and Oaxaca) remains unchanged while the technical change is which contributes to the deterioration of the PTF, causing it to fall.

With regard to region 2, inter regional analysis showed that there have been no improvements to the TFP and its components, the technical change which had a greater effect on TFP. It is similar to the interior of the region in behavior between the federative entities, and only the States of Puebla, San Luis Potosí and Veracruz are unchanged in technical efficiency. It refers to the region 3, improvements to TFP and technical change are not observed, however, the change in efficiency notes that there have been improvements in the analyzed period of three percentage points, which contributed to a shift towards its efficient frontier of reference. This result is consistent when scan at the intra-regional level already as shown in table 4, all the federal entities show no change in the use of factors, however, show a setback in their processes of innovation or technological change, contributing to the decline in the productivity of the region. For its part, the region 4 and region 3, does not present improvements in TFP and technical change. Likewise, it shows behavior similar to the region 3 in the sense that all States TFP as technical change, are improvements. However, all States remain unchanged in its technical efficiency, with the exception of the State of Colima that it presents a slight deterioration.

As shown in table 2, region 5 is located on the efficient frontier at the inter-regional level, both in 2003 and in 2008. However, the change in pro- 
ductivity and technological change suffer deterioration, while the change in efficiency remains unchanged. To the interior of the region, the change in TFP and technical change do not suffer improvements, while a technical change in the States of this region remain unchanged, with the exception of Baja California Sur, which is the only one who reported improvements in the use of factors by 50 percentage points.

In the context of inter-regional, region 6 does not show improvements, on the contrary, shows a decline in TFP and the changing technical (only the change in the use of factors remains unchanged) and neither does in TFP and technical change at the intra-regional level, while the change in efficiency remains unchanged in all the States of the region.

For its part, region 7, in the regional context presents both productivity and its components, notwithstanding the setbacks which the interregional analysis shows setbacks only in its portfolio and its technical change, while the change in efficiency remains unaltered. How to affect change technical and efficiency inter-regional productivity of the financial sector and insurance in the country can be seen in table 4 .

Table 4

Decomposition of Total Factor Productivity of the states

\begin{tabular}{|c|c|c|c|}
\hline Region 1 & TFP Change & Technical Change & Efficiency Change \\
\hline Chiapas & 0.50 & 0.50 & 1.00 \\
\hline Guerrero & 0.50 & 0.50 & 1.00 \\
\hline Oaxaca & 0.50 & 0.50 & 1.00 \\
\hline Region 2 & & & \\
\hline Campeche & 0.50 & 0.52 & 0.95 \\
\hline Hidalgo & 0.49 & 0.51 & 0.96 \\
\hline Puebla & 0.50 & 0.50 & 1.00 \\
\hline San Luis Potosí & 0.50 & 0.50 & 1.00 \\
\hline Tabasco & 0.50 & 0.50 & 0.99 \\
\hline
\end{tabular}




\begin{tabular}{|c|c|c|c|}
\hline Veracruz & 0.50 & 0.50 & 1.00 \\
\hline \multicolumn{4}{|l|}{ Region 3} \\
\hline Durango & 0.51 & 0.51 & 1.00 \\
\hline Guanajuato & 0.50 & 0.50 & 1.00 \\
\hline Michoacán & 0.50 & 0.50 & 1.00 \\
\hline Tlaxcala & 0.50 & 0.50 & 1.00 \\
\hline Zacatecas & 0.52 & 0.52 & 1.00 \\
\hline \multicolumn{4}{|l|}{ Region 4} \\
\hline Colima & 0.50 & 0.51 & 0.99 \\
\hline México & 0.50 & 0.50 & 1.00 \\
\hline Morelos & 0.50 & 0.50 & 1.00 \\
\hline Nayarit & 0.51 & 0.51 & 1.00 \\
\hline Querétaro & 0.50 & 0.50 & 1.00 \\
\hline Quintana Roo & 0.51 & 0.51 & 1.00 \\
\hline Sinaloa & 0.50 & 0.50 & 1.00 \\
\hline Yucatán & 0.50 & 0.50 & 1.00 \\
\hline \multicolumn{4}{|l|}{ Region 5} \\
\hline Baja California & 0.50 & 0.50 & 1.00 \\
\hline $\begin{array}{c}\text { Baja California } \\
\text { Sur }\end{array}$ & 0.79 & 0.52 & 1.52 \\
\hline Chihuahua & 0.50 & 0.50 & 1.00 \\
\hline Sonora & 0.50 & 0.50 & 1.00 \\
\hline Tamaulipas & 0.50 & 0.50 & 1.00 \\
\hline \multicolumn{4}{|l|}{ Region 6} \\
\hline Aguascalientes & 0.51 & 0.51 & 1.00 \\
\hline Coahuila & 0.50 & 0.50 & 1.00 \\
\hline Jalisco & 0.50 & 0.50 & 1.00 \\
\hline Nuevo León & 0.50 & 0.50 & 1.00 \\
\hline \multicolumn{4}{|l|}{ Region 7} \\
\hline DF & 0.50 & 0.50 & 1.00 \\
\hline
\end{tabular}

Note: All Malmquist indices are the average of the geometric mean of each region. Source: Based on data from INEGI. 


\section{CONCLUSIONS}

To count on information on production, investment and employment in the sector of financial services and insurance of the Mexican federal entities and the possibility of grouping them in regions according to criteria used by the INEGI and the use of techniques of data envelopment analysis and Malmquist index has allowed to build the technological frontier for regions and States of the country and run a scan on TFP, and its components: technical change and efficiency change.

As reported in the study, the technological frontier is determined by the region 7, which is not surprising, since this is the one that presents a relative more favourable situation, related to the variables considered in the methodology of the regional grouping, including, education, occupation, housing, urbanization, and socioeconomic status -this last subject comprises 24 selected indicators.

The results show that there is not an optimum use in the combination of the factors of production labor and capital, which is evidenced by the indicator of productivity of 0.71 , or, in percentage terms of $71 \%$. Likewise, as the results report, the change in productivity has decreased -adversely affecting the competitiveness of the country- more motivated by technical change than in efficiency. This leads to suggest that it is important to carry out actions that allow to improve technology and reduce the technological gap and the gap of productivity of Mexico, not abandoning actions to improve the investment and the qualification of the personnel employed in the financial and insurance system of Mexico. So, it has been able to answer the research question posed at the beginning of this document and to corroborate the hypothesis of departure.

In particular, it is observed the technological frontier was determined by the region 7 for the year 2003 and the year 2008 by the 6 and 7 . You 
could also identify regions that are on the efficient frontier under variable returns to scale, which in 2008 were the 5, 6 and 7 . In what refers to the change in regional productivity, seen setbacks in this, as well as in technical change, however to regions 5, 6 and 7 remain unchanged with respect to the use of factors and only the regions 3 and 4 show improvements in 3 percent and 0.04 percentage points, respectively. Therefore concludes that the productivity of the factors of the regions has not improved.

Inequalities in productivity of the regions are manifested to observe regional and intra-regional change. Therefore the results show has not improved this, influenced mainly by technical change, which does not contribute to improving the TFP. Likewise, only the State of Baja California Sur has achieved gains in efficiency of 50 percentage points, while the majority remained unchanged the use of factors (the States of Campeche, Hidalgo, Tabasco and Colima have worsened their situation with regard to the use of factors).

Derived from this study, found that it is important to seek mechanisms and actions that will result in better use of productive factors reducing the technological, productivity and competitiveness gap, whose impact would be on improving the technical efficiency.

We must not forget the second component of the change in productivity is the technical change, and this includes the behavior of the evolution of technology, and that in this study, is that it has greater impact on productivity, inhibiting their growth, what should seek mechanisms that contribute to the incorporation of innovations in the financial system and insurance. 


\section{REFERENCES}

Ablanedo-Rosas, J.H. and L.A. Gemoets. 2010. "Measuring the efficiency of Mexican airports", Journal of Air Transport Management, 16 (6): 343-345.

Asociación Latinoamericana de Integración (ALADI). 2003. La Brecha Digital y sus Repercusiones en los Países Miembros de la ALADI. ALADI/SEC/Estudio 157. Rev 1, 30 de julio de 2003.

Álvarez, I., O. Becerril, L. del Moral and R. Vergara. 2008. “Aplicación del Data Envelopment Analysis a la delimitación de la frontera tecnológica en México (1970-2003)”, Enlaces, 8(1): 1-18

Banker, R.D., A. Charnes y W.W. Cooper. 1984. "Some Models for Estimating Technical and Scale Inefficiencies in Data Envelopment Analysis”, Management Science, 30: 1078-1092.

Beeson, P.E. and S. Husted. 1989. "Patterns and determinants of productive efficiency in state manufacturing", Journal of Regional Science, 29(1): $15-28$

Belmonte Ureña, L.J. and J.A. Plaza. 2008. “Análisis de la eficiencia en las cooperativas de crédito en España. Una propuesta metodológica basada en el análisis envolvente de datos (DEA)", Revista de Economía Pública, Social y Cooperativa, 63:. 113-133.

Brown Grossman, Flor y Lilia Domínguez. 2004. "Evolución de la productividad de la industria mexicana: una aplicación con el método de Malmquist", Investigación Económica, LXIII(249): 75-100.

Caves Dowglas W., R. Christensen Laurits, and W. Diewert. 1982. "The theory of index numbers and the measurement of input, output, and productivity”. Econométrica. Vol. 50, No. 6. Pp. 1393-1414. 
Celso Arellano, P.L., J.H. Cortés. 2010. "Análisis de la eficiencia técnica relativa de la agroindustria azucarera: el caso de México", Revista Mexicana de Agronegocios, 14 (26): 202-213.

Coelli, T.J. 1996. A Guide to DEAP Versión 2.1.: A Data Envelopment Análisis (Computer) Program, University of New England, Armidale (mimeo).

Coelli, T.J. 1998. "A multi-stage methodology for the solution of orientated DEA models", Operations Research Letters, 23: 143-149.

Christensen, Jorgenson y Lau. 1973. "Trascendental logarithmic Production frontiers". The Review of Economics and Statistics. Vol. 51. Núm. 1. Pp. 28-45.

Farë, R. and C.A.K. Lovell. 1978. "Measuring the Technical Efficiency of Production", Journal of Economic Theory, 19: 150-162.

Farë, R., S. Grosskopf and C.A.K. Lovell. 1994. Production Frontiers, Cambridge University Press.

Farë, R., S. Grosskopf, M. Norris and Z. Zhang. 1994. "Productivity Growth, Technical Progress and Efficiency Changes in Industrialised Countries", American Economic Review, 84: 66-83.

Farrell M.J. 1957. "The Measurement of Productive Efficiency”, Journal of the Royal Statistical Society, 120 (3): 253-290.

Fuentes, H.J. and L. Armenta. 2006. "Las políticas públicas y la productividad: del diagnóstico a la solución efectiva. El caso de San Mateo Atenco", Análisis Económico, XXI (47): 281-306.

Griffin, W.L. and R.T. Woodward. 2011. "Determining policy-efficient management strategies in fisheries using data envelopment analysis (DEA)", Marine Policy. 35 (4): 496-507.

Guerrero, Rodolfo, J.L. Negrín. 2006. "Eficiencia del sistema bancario mexicano 1997-2004: una estimación dinámica”, Monetaria, 29 (3): 235-259. 
Gumbau, M. and J. Maudos. 1996. "Eficiencia productiva sectorial en las regiones españolas: una aproximación frontera”, Revista Española de Economía, 13(2): 239-260.

Guzmán, Isidoro and B. Escobar. 2011. "Cambios en productividad y creación de valor social en las cajas de ahorros españolas", El Trimestre Económico, 78(1): 235-253.

Hernández Arce, J. 2007. Enfoques alternativos para la estimación de eficiencias en la industria bancaria mexicana, edición electrónica, texto completo en www.eumed.net/libros/2007a/241/.

INEGI. 2004. Censos Económicos 2004, México. 2008. Sistema de Clasificación Industrial de América del Norte México SCIAN 2007. México. INEGI. 2009. Censos Económicos 2009, México. . 2000. XII Censo de Población y vivienda. Instituto Nacional de Estadística y Geografía. México. s/f. Metodología para la clasificación de las regiones socio económicas de México, consultado el 28\IV \2011, en <http://sc.inegi.org. $\mathrm{mx} /$ niveles/datosnbi/reg_soc_mexico.pdf.>

Jarque, C. 1981. A solution to the problem of Optimum Stratification in Multivariate Sampling, Journal of the Royal Statistical Society, Serie C., 30(2): 163-1692.

Klaus Schwab. 2012. The Global Competitiveness, Report 2012-2013. World Economic Forum.

Krüger J., U. Cantner and H. Hanusch. 2000. Total Factor Productivity, the East Asian Miracle, and the World Production Frontier, Review of World Economics, 136(1): 111-136. 
Lanteri L.N. 2002. Productividad, desarrollo tecnológico y eficiencia. La propuesta de los índices Malmquist, trabajo presentado en la XXXVll reunión de la Asociación Argentina de Economía Política, Tucuman, Argentina (mimeo).

Malmquist, Sten. 1953. "Index and Indiference surfaces". Trabajos de estadística y de investigación operativa. Vol. 4, num. 2. Pp 209-242.

Mankiw, N. G.; D. Romer \& D.N. Weil. 1992. “A Contribution to the Empirics of Economic Growth". The Quarterly Journal of Economics, Vol. 107, No. 2. (May, 1992), pp. 407-437.

Mariaca, D. R. 2003. Eficiencia de las empresas bancarias y su continuidad en el mercado (aplicación del método DEA), IISEC, Universidad de Salamanca, documento de trabajo, núm. 01/03.

Marín, Salvador, J. Gómez and G. Cándido. 2008. Eficiencia técnica en el sistema bancario español. Dimensión y rentabilidad, El Trimestre Económico, 65(4): 1017-1042.

Maudos J., J.M. Pastor and L. Serrano. 1998. Human capital in OECD countries: technical change, efficiency and productivity, Instituto Valenciano de Investigaciones Económicas, documento de trabajo, núm. WP-EC-98-19.

1999. Total Factor Productivity measurement and human capital in OECD countries, Economic Letters, 63: 39-44.

Moorteen, Richard H. 1961. "On measuring productivity and relative efficiency”. The Quarterly Journal of Economics. Vol. 73. No. 3. Pp. 451-467.

Navarro, J.C. and Z. Torres. 2006. Análisis de la eficiencia técnica global mediante la metodología DEA: evidencia empírica en la industria eléctrica mexicana en su fase de distribución, 1990-2003, Revista Nicolaita de Estudios Económicos,I(1): 9-28. 
Pollack, M. y A. García. 2004. Crecimiento, competitividad y equidad: rol del sector financiero. Comisión Económica para América Latina y el Caribe. Unidad de Estudios Especiales. Secretaría Ejecutiva. Santiago de Chile, noviembre del 2004.

Salinas, M., F. Pedraja and J. Salinas. 2001. Efectos del capital público y del capital humano sobre la productividad total de los factores en las regiones españolas, presentado en el II Encuentro de Economía Pública, España (mimeo)

Seiford, L.M. and R.M. Thrall. 1990. "Recent Developments in DEA: The Mathematical Approach to Frontier Analysis", Journal of Econometrics, 45: 7-38.

Solow, Robert M. 1956. "A contribution to the theory economic growth". The Quarterly Journal of Economics, Vol. 70, No. 1. pp. 65-94. 


\section{ANNEXES 7}

Annex A-1. Sector 52. Financial and Insurance Services

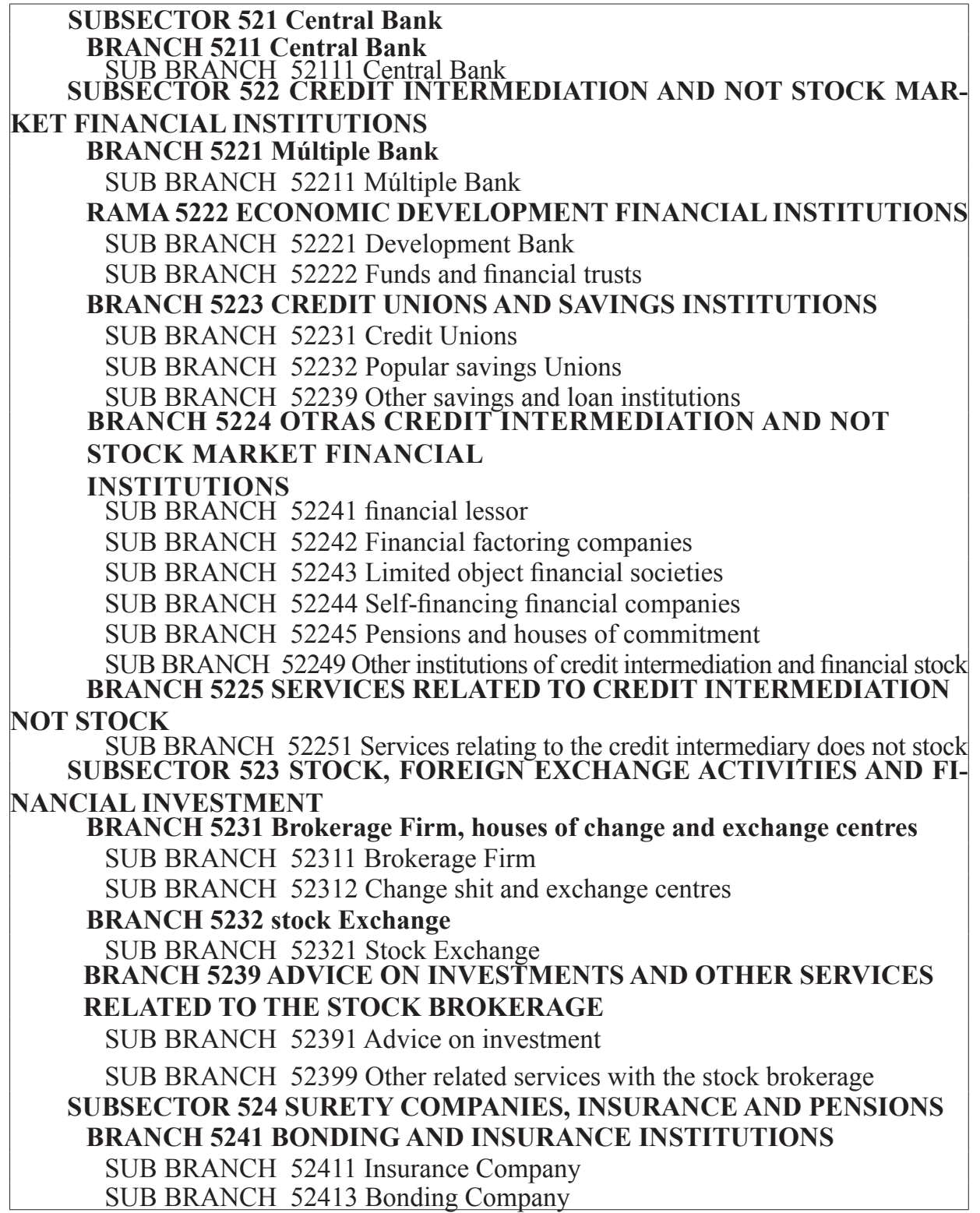


BRANCH 5242 RELATED SERVICES WITH THE INSURANCE AND SURETY BONDS

SUB BRANCH 52421 Agents, adjusters and managers of insurance and bonding

SUB BRANCH 52422 Boxes management independent insurance and Pension.

Source: Based on data from INEGI.

Annex A-2. Ratio input / output, 2003 and 2008

\begin{tabular}{|c|c|c|c|}
\hline Regions & Year & Investment/production & Labor / production \\
\hline 1 & 2003 & 45.15 & 4.61 \\
\hline 2 & 2003 & 54.77 & 5.83 \\
\hline 3 & 2003 & 28.39 & 1.54 \\
\hline 4 & 2003 & 48.20 & 2.91 \\
\hline 5 & 2003 & 45.43 & 5.50 \\
\hline 6 & 2003 & 30.27 & 1.74 \\
\hline 7 & 2003 & 24.69 & 1.00 \\
\hline 1 & 2008 & 2.84 & 5.98 \\
\hline 2 & 2008 & 1.53 & 5.80 \\
\hline 3 & 2008 & 3.26 & 2.66 \\
\hline 4 & 2008 & 1.60 & 3.42 \\
\hline 5 & 2008 & 1.44 & 7.21 \\
\hline 6 & 2008 & 0.83 & 1.55 \\
\hline 7 & 2008 & 1.00 & 1.00 \\
\hline
\end{tabular}

Source: Based on data from INEGI. 